[Review Paper]

\title{
Synthesis of Core-shell Structured Porous Materials and Applications as Catalysts and Precursors for Hollow Porous Materials
}

\author{
Masaki Окамото* \\ Dept. of Applied Chemistry, Tokyo Institute of Technology, 2-12-1 Ookayama, Meguro-ku, Tokyo 152-8552, JAPAN
}

(Received April 1, 2013)

\begin{abstract}
Ordered porous materials such as zeolites and ordered mesoporous silicas have important physical characteristics based on their high surface area and well-defined pore size. Control of the structure or shape of the ordered porous materials will provide new functions. This review focuses on core-shell structure; especially fabrication methods of core-shell structured zeolites with minimal defects are introduced. As an example of applications, MFI and TON-type zeolites with core-shell structure used as catalysts have high shape selectivity in the methylation of toluene with methanol and skeletal isomerization of tetradecane, respectively. As another application, synthesis of hollow porous materials from core-shell porous materials is also described. Decomposition of silica with dimethyl carbonate catalyzed by an alkali metal salt impregnated in the core was an effective method for selective removal of the core from the core-shell structure. Hollow porous materials show promise as vessels for drug delivery, catalyst vessels and microreactors.
\end{abstract}

Keywords

Core-shell structure, Hollow structure, Zeolite, Mesoporous silica, Shape selectivity

\section{Introduction}

Porous materials with highly ordered structures, such as zeolites and ordered mesoporous materials, have important physical characteristics based on their high surface area and well-defined pore size. Therefore, these materials are widely used for catalysts, catalyst supports, adsorbents and host materials, and continue to be evaluated for numerous applications. Formation of particular structures within the ordered porous materials may generate new functions. For example, the formation of nano-sized particles of zeolites results in higher catalytic activity ${ }^{1}$, and fabrication of porous membranes has the characteristic of gas separation ${ }^{2)}$.

Core-shell structure is one such characteristic structure. Combination of a core and a shell with different properties results in new functions. Catalysts based on core-shell structured materials often have highly effective catalytic activities.

The present review describes the synthesis of coreshell structured porous materials and applications to catalysts. The synthesis of MFI and TON-type zeolites with core-shell structure can be achieved with almost no formation of defects, and the resultant zeolites have high shape selectivities. Moreover, core-shell structured porous materials can be used for the fabrication of hollow porous materials by selective removal of

*E-mail: mokamoto@apc.titech.ac.jp the core (Fig. 1).

\section{Zeolites}

\section{1. Core-shell Structured Zeolites}

Zeolites used as catalysts often have characteristic selectivity for products called shape selectivity, which is caused by reaction inside confined pores. In contrast, acid sites on the external surface do not provide shape selectivity. To improve the selectivity, the acid sites on the external surface can be passivated by various methods such as coating with amorphous silica by chemical vapor deposition ${ }^{3) \sim 8)}$. Crystal overgrowth of an aluminum-containing zeolite (core) with an aluminum-free zeolite (shell) is also an effective method to passivate the external acid sites. Several groups have reported MFI-type zeolites with the core-shell structure $^{9 \sim 14)}$. However, the presence of pinholes in the aluminum-free shell indicates imperfect passivation $^{12)}$.

The ideal method for passivating the external surface is crystal overgrowth of the aluminum-free zeolite (shell zeolite) on single crystals of zeolite (core zeolite) with no defects. However, defects usually develop and cause mesopores to form in the preparation of zeolites. If zeolites with defects are used as the core zeolites, defects then presumably grow in the shell zeolites and act as pinholes, preventing perfect passivation of the external surface. Therefore, it is important to synthe- 
size core-shell zeolite without defects.

The conventional synthesis of zeolites uses hydroxyl anion as the mineralizing agent. If the mineralizing agent is changed from hydroxyl ion to fluoride ion, reaction gives large particles without defects ${ }^{15), 16)}$. Large crystals are thought to be formed if nucleation and crystal growth occur at slower rates over longer times ${ }^{16}$, and occlusion of fluoride ion results in charge balance of the structure-directing agent without requiring the formation of $\mathrm{Si}^{-} \mathrm{O}^{-}$defects ${ }^{17)}$. Therefore, the use of fluoride ion provides a simple method for obtaining core zeolite with minimal defects.

This review describes the synthesis methods of coreshell structured MFI and TON-type zeolites with minimal defects and application to catalysts.

\section{1. 1. MFI-type Zeolite}

MFI-type zeolite is one of the most widely used zeolites; for example, the catalysis of shape-selective reactions such as disproportionation of toluene and methylation of toluene with methanol to form $p$-xylene selectively. Coating of core zeolite with small crystallites of MFI-type zeolite by adding the core to a synthesis gel of aluminum-free zeolite demonstrated both successful epitaxial overgrowth of small crystallites on the parent zeolite and high catalytic performance with the obtained core-shell zeolite for methylation of toluene with methanol to give highly selective formation of $p$ xylene ${ }^{18), 19)}$.

We also prepared MFI-type zeolite with the coreshell structure by crystal overgrowth of aluminumcontaining zeolite (core) with aluminum-free zeolite (shell) (Fig. 2) ${ }^{20)}$. The synthesis conditions for crystal overgrowth without defects were examined. As the core zeolite, aluminum-containing zeolite was synthesized in the presence of fluoride ion or hydroxide ion as mineralizing agent. The as-synthesized or calcined core zeolite was added to the synthesis gel of aluminumfree zeolite, and the mixtures were hydrothermally treated to overgrow the core with the shell. In the formation of the shell, fluoride ion or hydroxide ion was used. The results are summarized in Table 1 .

Zeolite particles prepared by the conventional method $(\mathrm{CA}(\mathrm{C}))$ had a step around $0.5\left(p / p_{0}\right)$ in the nitrogen adsorption isotherm, indicating the presence of mesopores. On the other hand, core synthesis using fluoride ion $(\mathrm{CF}(\mathrm{C}))$ resulted in no formation of mesopores. These results are consistent with the findings of previous studies ${ }^{15), 16)}$. During second hydrothermal synthesis on $\mathrm{CF}(\mathrm{C})$ and $\mathrm{CF}(\mathrm{NC})$ cores in the presence of fluoride ion, the particles grow from 15 to $18 \mu \mathrm{m}$ along major axis (Table 1), strongly suggesting that crystal overgrowth occurs on the core particles during the second synthesis. However, using $\mathrm{CF}(\mathrm{C})$ as the core, nitrogen adsorption analysis of $\mathrm{CF}(\mathrm{C}) \mathrm{SF}$ revealed the

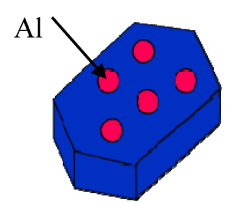

core $(\mathrm{Si}, \mathrm{Al})$

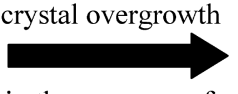

in the presence of fluoride ion

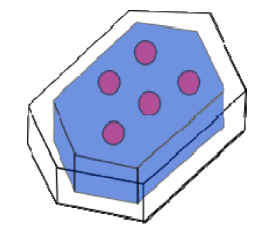

shell ( $\mathrm{Si})$
Fig. 2 Preparation of MFI-type Zeolites with Core-shell Structure ${ }^{20)}$

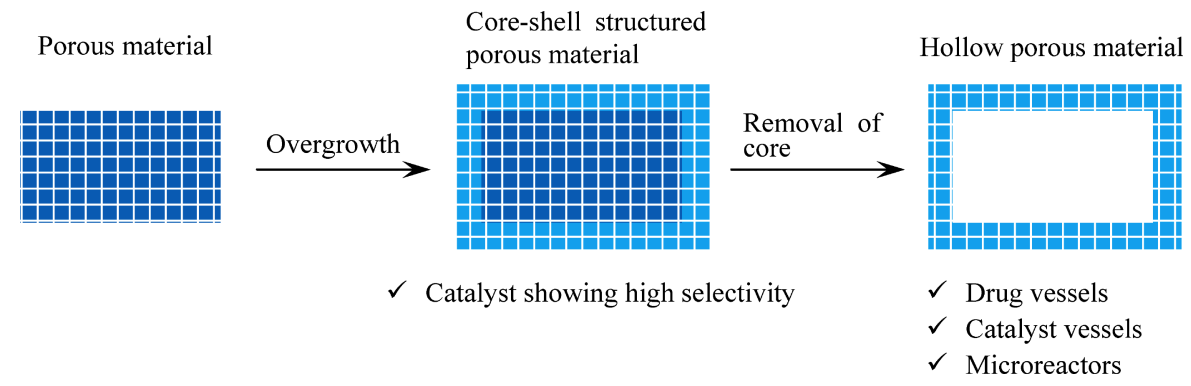

Fig. 1 Scheme of Fabrication of Core-shell Structured and Hollow Porous Materials

Table 1 Characterization of Core and Core-shell Zeolites ${ }^{20)}$

\begin{tabular}{|c|c|c|c|c|c|}
\hline Zeolite & \multicolumn{2}{|c|}{ Core synthesis conditions } & Shell synthesis conditions & $\begin{array}{l}\text { Length of the particle's major } \\
\qquad \text { axis }[\mu \mathrm{m}]^{\text {a) }}\end{array}$ & $\begin{array}{c}\text { Step at } 0.4-0.6\left(p / p_{0}\right) \text { in } \\
\text { isotherms }\end{array}$ \\
\hline $\mathrm{CF}(\mathrm{C})$ & with $\mathrm{F}^{-}$ & calcined & - & 15 & not observed \\
\hline $\mathrm{CF}(\mathrm{C}) \mathrm{SF}$ & with $\mathrm{F}^{-}$ & calcined & with $\mathrm{F}^{-}$ & 18 & observed \\
\hline $\mathrm{CF}(\mathrm{NC}) \mathrm{SF}$ & with $\mathrm{F}^{-}$ & not calcined & with $\mathrm{F}^{-}$ & 18 & not observed \\
\hline $\mathrm{CF}(\mathrm{NC}) \mathrm{SA}$ & with $\mathrm{F}^{-}$ & not calcined & without $\mathrm{F}^{-}$ & 16 & not determined \\
\hline $\mathrm{CA}(\mathrm{C})$ & without $\mathrm{F}^{-}$ & calcined & - & 9 & observed \\
\hline $\mathrm{CA}(\mathrm{NC}) \mathrm{SF}$ & without $\mathrm{F}^{-}$ & not calcined & with $\mathrm{F}^{-}$ & 15 & observed \\
\hline
\end{tabular}

a) Calculated using SEM images.

b) Nitrogen adsorption-desorption measurement. 
formation of pinholes. If overgrowth is attempted in the absence of fluoride ion ( $\mathrm{CF}(\mathrm{NC}) \mathrm{SA})$, core size does not increase during the second hydrothermal synthesis. If $\mathrm{CA}(\mathrm{NC})$ core is used, particle size increases from 9 to $15 \mu \mathrm{m}$ during the second hydrothermal synthesis in the presence of fluoride ion. The amount of silicon in the synthesis gel used for shell formation is equal to the amount of silicon in the core, so the shell volume should be the same as that of the core if perfect crystal overgrowth were to occur. However, the volume of each particle more than doubles, likely due to dissolution of part of the cores and formation of new zeolite particles during the second hydrothermal synthesis. These findings suggest that use of fluoride ion is essential both in the synthesis of the core and in the crystal overgrowth with the shell to obtain core-shell structured zeolite without mesopores (i.e., with minimal defects). Moreover, use of the core without calcination is also necessary to avoid the formation of mesopores due to defects. Figure 3 shows scanning electron microscope (SEM) images of the core synthesized in the presence of fluoride ion $(\mathrm{CF}(\mathrm{C}))$ and the core-shell structured zeolite formed by crystal overgrowth of as-synthesized core in the presence of fluoride ion $(\mathrm{CF}(\mathrm{NC}) \mathrm{SF})$. After crystal overgrowth, the particle size increased.

Figure 4 shows the distribution of aluminum in a cross-section of the core-shell structured zeolite (CF(NC)SF) determined by energy-dispersive X-ray (EDX) spectroscopy. The Si distribution in the shell
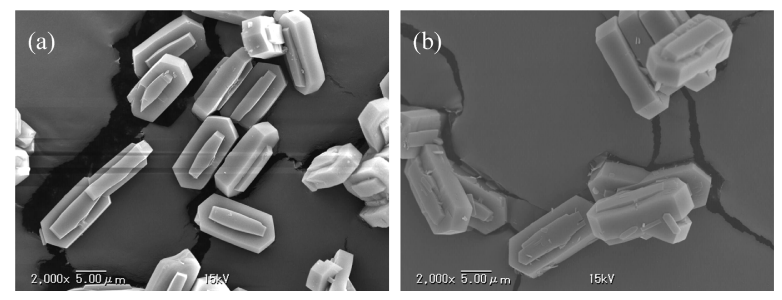

Fig. 3 SEM Images of MFI-type Zeolites: (a) core $(\mathrm{CF}(\mathrm{C}))$; (b) core-shell $(\mathrm{CF}(\mathrm{NC}) \mathrm{SF})^{20)}$ was convex upwards, whereas the Al distribution was concave upwards. The EDX signal intensity at any point is the average of signal intensities of its surroundings. The intensity of $\mathrm{Al}$ in the shell was lower (not zero) than that in the core. Considering the EDX resolution, this suggests that the external surface was almost aluminum-free.

The core-shell structured zeolite was applied to synthesis of a catalyst for methylation of toluene with methanol. The results are summarized in Table 2 . Synthesis of a shell around the core, formed in the presence of fluoride ion ( $\mathrm{CF}(\mathrm{C}) \mathrm{SF}$ and $\mathrm{CF}(\mathrm{NC}) \mathrm{SF})$, increased the fraction of $p$-xylene obtained, suggesting that the shell successfully passivated the acid sites on the external surface of the core and that $p$-xylene has diffusivity in the pores than $o$ - and $m$-xylenes ${ }^{21)}$. $\mathrm{CF}(\mathrm{NC}) \mathrm{SF}$ gives a higher yield of $p$-xylene, probably due to the presence of mesopores caused by defects in $\mathrm{CF}(\mathrm{C}) \mathrm{SF}$. Through these mesopores, $o$ - and $m$ xylenes, both of which are larger than the micropore size of the MFI-type structure, can penetrate the shell and reach the outside of the core. $\mathrm{CA}(\mathrm{NC}) \mathrm{SF}$ shows

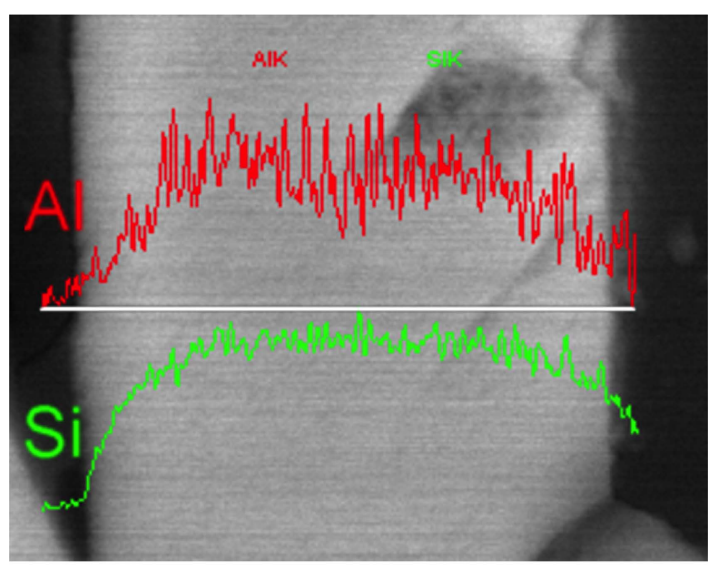

The white line is for analysis.

Fig. 4 Aluminum and Silicon Distributions across the Cross-section of Core-shell Zeolite $\mathrm{CF}(\mathrm{NC}) \mathrm{SF}^{20}$ )

Table 2 Methylation of Toluene with Methanol Catalyzed by Core and Core-shell Zeolites ${ }^{20)}$

\begin{tabular}{|c|c|c|c|c|c|c|}
\hline Catalyst & & $\mathrm{CF}(\mathrm{C})$ & $\mathrm{CF}(\mathrm{C}) \mathrm{SF}$ & $\mathrm{CF}(\mathrm{NC}) \mathrm{SF}$ & $\mathrm{CA}(\mathrm{C})$ & $\mathrm{CA}(\mathrm{NC}) \mathrm{SF}$ \\
\hline Toluene conversion & {$[\%]$} & 24.9 & 20.8 & 20.8 & 27.3 & 26.1 \\
\hline Yield & {$[\%]$} & & & & & \\
\hline$p$-Xylene & & 14.4 & 17.0 & 17.8 & 11.5 & 11.3 \\
\hline$m$-Xylene & & 4.3 & 1.0 & 0.5 & 8.2 & 8.1 \\
\hline$o$-Xylene & & 1.9 & 0.5 & 0.3 & 3.3 & 3.0 \\
\hline Ethylbenzene & & 0.4 & 0.3 & 0.2 & 0.1 & 0.3 \\
\hline Trimethylbenzene and ethylmethylbenzene & & 3.9 & 2.0 & 2.0 & 4.2 & 3.4 \\
\hline Fraction of xylene & {$[\%]$} & & & & & \\
\hline$p$-Xylene & & 69.9 & 91.9 & 95.8 & 50.0 & 50.4 \\
\hline$m$-Xylene & & 20.9 & 5.4 & 2.9 & 35.7 & 36.2 \\
\hline$o$-Xylene & & 9.2 & 2.7 & 1.3 & 14.3 & 13.4 \\
\hline
\end{tabular}

Reaction temperature $400^{\circ} \mathrm{C}$, time of stream $2 \mathrm{~h}, W / F 0.15 \mathrm{~kg}$ (catalyst) h mol ${ }^{-1}$, toluene $42.0 \mathrm{kPa}$, methanol $42.0 \mathrm{kPa}$. 


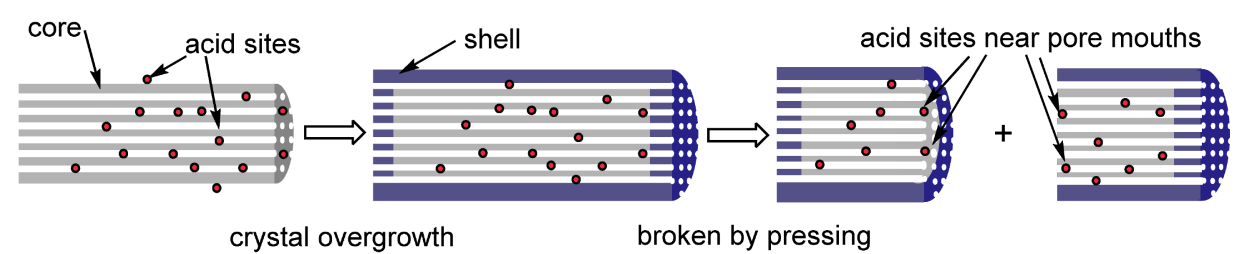

Fig. 5 Scheme for the Preparation of TON-type Zeolites with Core-shell Structure ${ }^{32)}$

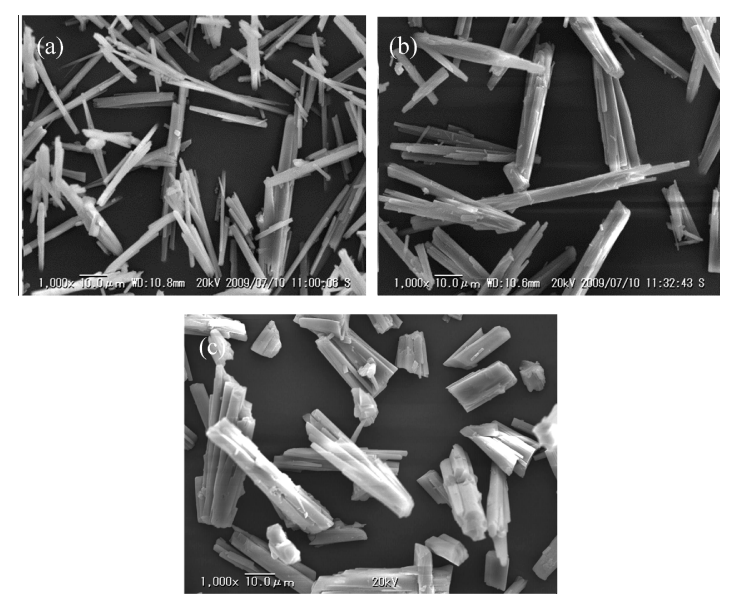

Fig. 6 SEM Images of TON-type Zeolites: (a) core, (b) core-shell, (c) core-shell pressed at $10 \mathrm{MPa}^{32)}$

low selectivity for $p$-xylene. It is likely that during synthesis of the shell, part of the CA dissolves in the synthesis gel and forms new particles together with the fumed silica used as a silica source. The catalysis experiments also indicate that only the shell of the sample $\mathrm{CF}(\mathrm{NC}) \mathrm{SF}$ completely covers the core. Furthermore, the core-shell zeolite has minimal defects not only at the boundary between the core and shell but also inside the particles, so the mechanical stability is higher.

\section{1. 2. TON-type Zeolite}

TON-type zeolite is one of the excellent catalysts for skeletal isomerization of normal paraffin. TON-type zeolite has needle-shaped crystals, and the onedimensional micropores are parallel to the major axis of the crystal. The reaction mechanism of the isomerization using a TON-type zeolite catalyst was explained in terms of pore mouth catalysis ${ }^{22)}$ 28) or shape selective catalysis inside the pores ${ }^{29)}$ 31). In any case, external acid sites on the sides of the needle-shaped crystals are likely to induce cracking of alkanes rather than isomerization. Passivation of these external sites, especially those on the sides of the needle-shaped crystals, leads to highly selective catalysts for isomerization. Thus, core-shell structured zeolite catalyst with minimal defects is also suitable for isomerization.

TON-type zeolite by passivation of the external surface of an aluminum-containing TON-type zeolite was prepared, and was accomplished by crystal overgrowth of an aluminum-free TON-type zeolite shell (Fig. 5) ${ }^{32}$.
TON-type zeolite can also be synthesized in the presence of fluoride ion as a mineralizing reagent to give defect-free crystals ${ }^{33)}$. Under the synthetic conditions using fluoride ion, core formation and crystal overgrowth were performed. After overgrowth of the core zeolite with the shell, the needle-like crystal shape was maintained and the crystal size was enlarged (Fig. 6). The crystal shape and the X-ray diffraction (XRD) pattern indicated that no crystals other than TON-type zeolite were formed. The overgrowth increased the length and the width. These results indicated that the core zeolite was covered with a shell of aluminum-free zeolite. The aluminum distribution in the zeolite with the core-shell structure examined by the cross-section analysis also showed overgrowth with the aluminum-free shell (i.e., external acidic sites were passivated by the shell ${ }^{32)}$. Nitrogen adsorption analysis of the coreshell zeolite revealed the absence of mesopores due to defects $^{32)}$.

After impregnation with platinum, the TON-type zeolite catalysts were tested for tetradecane hydroisomerization using a continuous flow reactor. The core-shell structured zeolite did not have external acid sites and was therefore not expected to induce cracking. The results are summarized in Table 3 . The products were branched tetradecanes and shorter alkanes formed as skeletal isomers and cracked products, respectively. Overgrowth of an aluminum-free shell on the core zeolite caused lower conversion and higher selectivity, indicating that the external acid sites are detrimental to skeletal isomerization.

Crystal overgrowth of the zeolite shell passivated the acid sites near the pore mouths as well as on the sides of the needle-like crystals, as shown in Fig. 5. As skeletal isomerization proceeds inside the micropores, the long distance from the pore entrances to the acid sites inside the pores apparently hinders isomerization. If the alkane is isomerized mainly at the pore mouths, crystal overgrowth also hampers the isomerization process. As mentioned above, the overgrowth decreased conversion but also increased selectivity. To increase both activity and selectivity, only the acid sites on the sides of the needle-like crystals should be passivated. Core-shell zeolite was pressed at $10 \mathrm{MPa}$ to make shorter crystal fragments. The SEM images of the broken crystals are shown in Fig. 6(c). The pressing decreased only the length of the crystals, and did not 
Table 3 Skeletal Isomerization of Tetradecane Catalyzed by Platinum-loaded TON-type Zeolites ${ }^{32)}$

\begin{tabular}{|c|c|c|c|}
\hline \multirow{2}{*}{ Catalyst } & \multirow{2}{*}{ Tetradecane conversion [\%] } & \multicolumn{2}{|c|}{ Tetradecane isomers } \\
\hline & & Selectivity [\%] & Yield $[\%]$ \\
\hline Core & 65 & 54 & 35 \\
\hline Core-shell & 49 & 76 & 37 \\
\hline Core-shell broken at $10 \mathrm{MPa}$ & 73 & 77 & 56 \\
\hline Core broken at $20 \mathrm{MPa}$ & 76 & 64 & 49 \\
\hline Core (broken at $20 \mathrm{MPa}$ )-shell broken at $10 \mathrm{MPa}$ & 78 & 79 & 62 \\
\hline Conventional TON-type zeolite & 67 & 47 & 32 \\
\hline
\end{tabular}

Reaction temperature $380{ }^{\circ} \mathrm{C}$, time on stream $6 \mathrm{~h}$, catalyst amount $1.5 \mathrm{~g}$, Pt amount $0.5 \mathrm{wt} \%, n$-tetradecane $0.12 \mathrm{mmol}$ $\min ^{-1}, \mathrm{H}_{2} 0.58 \mathrm{mmol} \mathrm{min}^{-1}$, total pressure $3 \mathrm{MPa}$. .

change the width, indicating that new pore mouths not covered with the aluminum-free shell were formed by the pressing (Fig. 5). Using the broken zeolite fragments as catalysts for skeletal isomerization resulted in increased conversion to $73 \%$ and selectivity remained high $(77 \%)$.

In general, zeolite catalysts with small particles show high catalytic activity. To obtain a core-shell product with higher catalytic performance, the core was broken at $20 \mathrm{MPa}$ prior to crystal overgrowth to form shorter crystals. Then, after crystal overgrowth, the resultant core-shell zeolite was pressed at $10 \mathrm{MPa}$. The resultant core-shell structured crystals were used as the isomerization catalyst. The highest conversion (78\%) and selectivity (79\%) were obtained (Table 3). Comparing the results obtained using the TON-type zeolite synthesized by a conventional method, we observed that the broken zeolite fragments with the core-shell structure showed higher catalytic performance.

As described above, we demonstrated the synthesis of MFI and TON-type zeolites with core-shell structure which showed high shape selectivity, indicating that formation of the core-shell structure can be applied to other types of zeolite to obtain catalysts with high catalytic performance.

\section{2. Hollow Zeolites}

Hollow zeolites can be formed from core-shell structured zeolite. Differences between the core and shell properties can be exploited to remove the core zeolite selectively. Hollow structure is a distinctive structure, with the hollow core connected to the outside only by pores. Considering this property, hollow porous materials can be used as drug vessels, catalyst vessels and microreactors.

In general, hollow zeolites are fabricated using hard templates such as polystyrene beads ${ }^{34)}$-38). Small zeolite particles are gathered around the beads to form zeolite shell, and the beads are removed by calcination. Thus, hollow zeolite particles have mesopores together with micropores of the crystal structure of the zeolite, and are not true hollow zeolites. Hollow zeolites with only micropores are more suitable for applications to drug vessels, catalyst vessels and microreactors. As

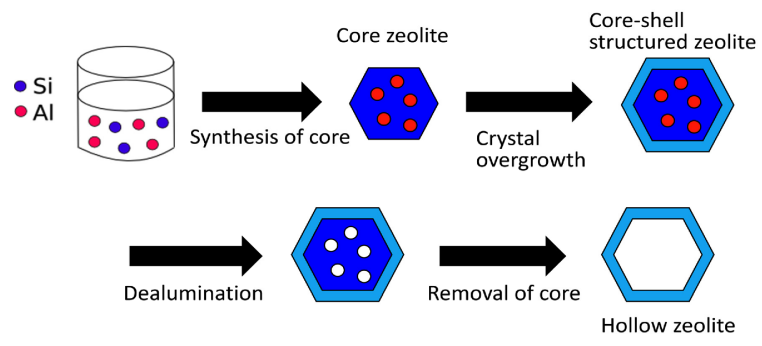

Fig. 7 Scheme for the Synthesis of Hollow Zeolite ${ }^{42)}$

described above, core-shell structured zeolites can be synthesized by crystal overgrowth, and have no mesopores. Selective removal of the core from such zeolites could give hollow zeolites without mesopores. Since zeolite consists of silica, decomposition of silica with dimethyl carbonate (DMC) was applied to the removal of the core.

Metal oxides react with DMC to form metal methox$\operatorname{ides}^{39) \sim 41)}$. For example, silica is decomposed by the reaction with DMC using an alkali metal salt catalyst to form tetramethoxysilane and carbon dioxide ${ }^{39), 40)}$. This reaction can be applied to the chemical decomposition of silica for the fabrication of hollow structures if the catalyst is selectively loaded at areas where removal of silica is required. Selective impregnation of the catalyst will exploit differences in the properties of silica, such as hydrophobic and hydrophilic properties. If an alkali metal salt as the catalyst is impregnated on silica, the salt favors impregnation on the hydrophilic surface. Thus, it is possible to achieve selective decomposition with DMC.

The scheme of fabrication of hollow zeolites is shown in Fig. $\mathbf{7}^{42)}$. The beta-type (hereinafter, *BEA-type) zeolite with aluminum-containing core and aluminumfree shell was synthesized in the presence of fluoride ion to inhibit formation of mesopores. After aluminum in the core was removed by acid treatment to form the hydrophilic core, sodium acetate as a silica decomposition catalyst was impregnated into the zeolite. The salt catalyst was loaded selectively in the hydrophilic core, not in the hydrophobic shell. The zeolite with the catalyst was exposed to $\mathrm{DMC}$ vapor at $380{ }^{\circ} \mathrm{C}$ 
to decompose the core selectively. SEM images of the hollow zeolite and its cross section are shown in Fig. 8. The post-treatment of core-shell structured materials with DMC is a useful method for fabricating hollow structures.

\section{Mesoporous Silica}

\section{1. Core-shell Structured Mesoporous Silica}

Ordered mesoporous silicas are synthesized in the presence of surfactants such as cetyltrimethylammonium salts, which form micelles and act as templates of mesopores ${ }^{43)}$. Fabrication of core-shell structured mesoporous silicas by overgrowth is easier than that of zeolites. However, only a few studies on the fabrication and their application have been reported ${ }^{44) \sim 46)}$. Core-shell structured dual-mesoporous silica spheres with larger mesopores in the core were formed ${ }^{44)}$. Preparation of novel mono-dispersed silica spheres with mesopores in the radial orientation was reported ${ }^{47)}$, and growth of the spheres could be obtained with mercaptopropyl-modified silica to form a core-shell structure ${ }^{45)}$. Mesoporous silica spheres were also synthesized with sulfonic acid-functionalized core and shell grafted with propyl groups by overgrowth ${ }^{46)}$. Such silica spheres showed high catalytic performance in the condensation of 2-methylfuran with acetone ${ }^{46)}$.

In accordance with Yano's method ${ }^{45)}$, we prepared mesoporous silica spheres with hydrophilic pure silica core and hydrophobic silica shell grafted with propyl groups by particle growth to apply fabrication of hollow
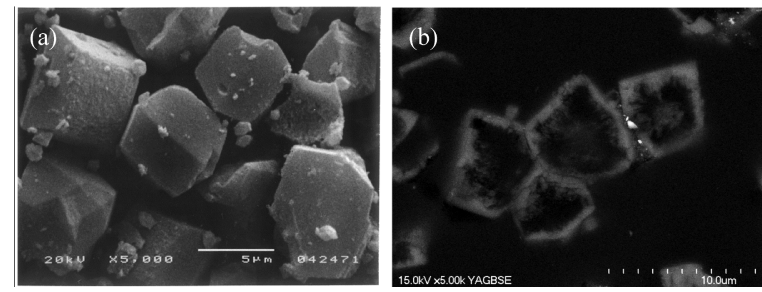

Fig. 8 SEM Images of Hollow * BEA-type Zeolites: (a) particles, (b) cross-section of particles mesoporous silica spheres.

\section{2. Hollow Mesoporous Silica}

Hollow mesoporous materials have been synthesized by various methods. To form hollow structures, hard $^{48) \sim 54)}$ and soft ${ }^{55), 66)}$ templates are usually used. Polystyrene beads have been typically used as hard templates, and were removed by calcination to form hollow spheres ${ }^{48), 49), 52) \sim 54)}$. The hard template method is simple, providing readily controllable particle size and shell thickness; however, difficulty has been encountered in forming radially oriented, ordered mesopores with this method. Recently, however, hollow spheres with radially oriented, ordered mesopores were successfully synthesized using a hard template ${ }^{49), 53), 54)}$. In other studies, soft templates such as bubbles ${ }^{55)}$-58) and emulsions ${ }^{60) \sim 66)}$ have been used. The soft template method is slightly simpler than the hard template method. However, controlling the shape and shell thickness was generally difficult.

We fabricated hollow mesoporous silica from mesoporous silica with hydrophilic pure silica core and hydrophobic silica shell grafted with propyl groups by selective removal of core silica ${ }^{67)}$. Silica decomposition with DMC catalyzed by an alkali metal salt was used to remove the core in the same manner as fabrication of hollow zeolite. Figure 9 shows the scheme of fabrication of hollow mesoporous silica. Mesoporous spheres with silica core and propyl-modified silica shell were formed (step 1). Sodium salt (a silica decomposition catalyst) was loaded selectively into the core by exploiting the hydrophilicity difference between the core and the shell (step 2), and the hydrophilic core was selectively removed by DMC treatment (step 3). As a result, silica spheres with radial and ordered mesopores could be synthesized.

Figure 10 shows a SEM image of the hollow mesoporous spheres. The hollow silica spheres were monodispersed. A transmission electron microscope (TEM) image of the DMC-treated spheres also confirmed vacant centers of the spheres. TEM observations revealed radial orientation of the ordered mesopores; however, slight disturbance of the order was observed.

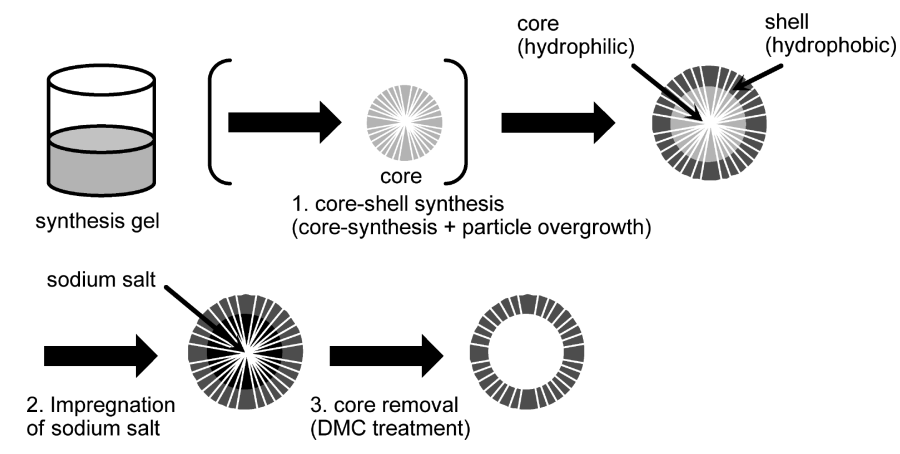

Fig. 9 Scheme for the Synthesis of Hollow Mesoporous Silica Spheres ${ }^{67)}$ 

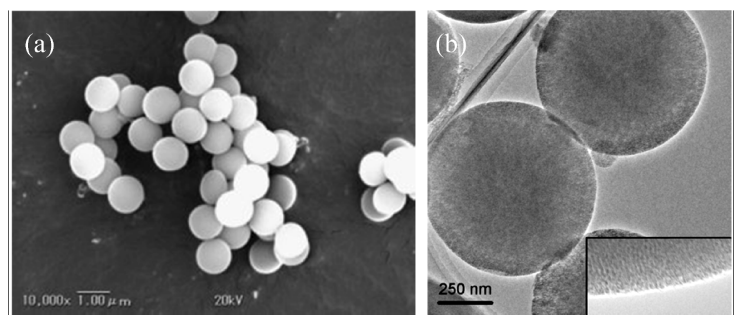

Fig. 10 SEM (a) and TEM (b) Images of Hollow Mesoporous Silica Spheres $^{67)}$

Such hollow mesoporous materials show promise as drug carriers for drug vessels, microreactors, and so on. We demonstrated that the hollow spheres could be used as drug vessels. 9-Phenylanthracene was encapsulated in the hollow spheres and released as vapor under a continuous flow of air at $130{ }^{\circ} \mathrm{C}$. Release rate of the encapsulated anthracene was almost half of the rate of the free anthracene determined by its vapor pressure. The anthracene encapsulated in the hollow spheres was released through the pores. The release rate was probably determined by its diffusion through the pores. This result indicates that hollow mesoporous spheres have potential applications such as capsules for the controlled release of molecules, for example, insect repellent, into the vapor phase.

\section{Conclusions}

Formation of the distinctive structures of the ordered porous materials results in new functions. We focused core-shell and hollow structures as distinctive structures. In the synthesis of zeolites with core-shell structures with minimal defects, use of fluoride ion as a mineralizing agent is essential, both for the formation of the core and crystal overgrowth of the shell, and use of as-synthesized core is also important. The resultant zeolites showed high shape selectivity because of no pinholes in the shell and perfect passivation of the acid sites on the external surface with the shell. Ordered porous silicas with core-shell structure can be used as precursors of hollow silica with ordered pores. The core could be selectively removed from the core-shell structure by the decomposition reaction of silica with DMC catalyzed by an alkali metal salt, which was selectively impregnated in the hydrophilic core. Controlling the location of the salt in the material led to the selective formation of various structures and shapes of this material by chemical decomposition with DMC.

\section{Acknowledgment}

This work was financially supported by JSPS KAKENHI Grant Number 21550187 and 24550231.

\section{References}

1) Tosheva, L., Valtchev, V. P., Chem. Mater., 17, 2494 (2005).

2) Caro, J., Noack, M., Micropor. Mesopor. Mater., 115, 215 (2008)

3) Niwa, M., Kato, M., Hattori, T., Murakami, Y., J. Phys. Chem., 90, 6233 (1986)

4) Hibino, T., Niwa, M., Murakami, Y., J. Catal., 128, 551 (1991).

5) Wang, I., Ay, C.-L., Lee, B.-J., Chen, M.-H., Appl. Catal., 54, 257 (1989).

6) Rtiger, H. P., Krkner, M., Miiller, K. P., O’Connor, C. T., Micropor. Mesopor. Mater, 21, 607 (1998).

7) Manstein, H., Möller, K. P., Böhringer, W., O’Connor, C. T., Micropor. Mesopor. Mater, 51, 35 (2002).

8) O’Connor, C. T., Möller, K. P., Manstein, H., J. Mol. Catal. A, 181, 15 (2002).

9) Rollmann, L. D., US Pat. 4203869 (1980).

10) Lee, C. S., Park, T. J., Lee, X. Y., Appl. Catal. A: General, 95 , 151 (1993).

11) Weber, R. W., Fletcher, J. C. Q., Möller, K. P., O'Connor, C. T., Micropor. Mater., 7, 15 (1996).

12) Bouizi, Y., Rouleau, L., Valtchev, V. P., Chem. Mater., 18, 4959 (2006).

13) Li, Q., Wang, Z., Hedlund, J., Creaser, O., Zhang, H., Zou, X., Bons, A., Micropor. Mesopor. Mater, 78, 1 (2005).

14) Miyamoto, M., Kamei, T., Nishiyama, N., Egashira, Y., Ueyama, K., Adv. Mater., 17, 1985 (2005).

15) Guth, J. L., Kessler, H., Wey, R., Stud. Surf. Sci. Catal., 28, 121 (1986).

16) Axon, S. A., Klinowski, J., Appl. Catal. A: General, 81, 27 (1992).

17) Koller, H., Wollker, A., Villaescusa, L. A., Díaz-Cabañas, M. J., Valencia, S., Camblor, M. A., J. Am. Chem. Soc., 121, 3368 (1999).

18) Vu, D. V., Miyamoto, M., Nishiyama, N., Egashira, Y., Ueyama, K., J. Catal., 243, 389 (2006).

19) Vu, D. V., Miyamoto, M., Nishiyama, N., Ichikawa, S., Egashira, Y., Ueyama, K., Micropor. Mesopor. Mater., 115, 106 (2008).

20) Okamoto, M., Osafune, Y., Micropor. Mesopor. Mater, 143, 413 (2011).

21) Olson, D. H., Haag, W. O., in: Whyte Jr., T. E., Dalla Betta, R. A., Derouane, E. G., Baker, R. T. K., (Eds.), Catalytic Materials - Relationship between Structure and Reactivity, ACS Symposium Series 248, Washington, DC, 1984, p. 275.

22) Ernst, S., Weitkamp, J., Martens, J. A., Jacobs, P. A., Appl. Catal., 48, 138 (1989).

23) Martens, J. A., Parton, R., Uytterhoeven, L., Jacobs, P. A., Froment, G. F., Appl. Catal., 76, 95 (1991).

24) Martens, J. A., Souverijns, W., Verrelst, W., Parton, R., Froment, G. F., Jacobs, P. A., Angew. Chem., Int. Ed. Engl., 34, 2528 (1995).

25) Claude, M. C., Martens, J. A., J. Catal., 190, 39 (2000).

26) Claude, M. C., Vanbutsele, G., Martens, J. A., J. Catal., 203, 213 (2001).

27) Laxmi Narasimhan, C. S., Thybaut, J. W., Marin, G. B., Jacobs, P. A., Martens, J. A., Denayer, J. F., Baron, G. V., J. Catal., 220, 399 (2003).

28) Denayer, J. F., Baron, G. V., Vanbutsele, G., Jacobs, P. A., Martens, J. A., Chem. Eng. Sci., 54, 3553 (1999).

29) Sastre, G., Chica, A., Corma, A., J. Catal., 195, 227 (2000).

30) Webb III, E. B., Grest, G. S., Catal. Lett., 56, 95 (1998).

31) Maesen, T. L. M., Schenk, M., Vlugt, T. J. H., de Jonge, J. P., Smit, B., J. Catal., 188, 403 (1999).

32) Okamoto, M., Huang, L., Yamano, M., Sawayama, S., Nishimura, Y., Appl. Catal. A: General, 455, 122 (2013).

33) Patarin, J., Lamblin, J.-M., Faust, A.-C., Guth, J.-L., Raatz, F., 
EU Pat. 0345106 (1989).

34) Wang, X. D., Yang, W. L., Tang, Y., Wang, Y. J., Fu, S. K., Gao, Z., Chem. Commun., 2161 (2000).

35) Dong, A., Wang, Y., Tang, Y., Ren, N., Zhang, Y., Gao, Z., Chem. Mater, 14, 3217 (2002).

36) Dong, A., Wang, Y., Wang, D., Yang, W., Zhang, Y., Ren, N., Gao, Z., Tang, Y., Micropor. Mesopor. Mater, 64, 69 (2003).

37) Dong, A., Ren, N., Yang, W., Wang, Y., Zhang, Y., Wang, D., Hu, J., Gao, Z., Tang, Y., Adv. Funct. Mater, 13, 943 (2003).

38) Valtchev, V., Mintva, S., Micropor. Mesopor. Mater., 43, 41 (2001).

39) Suzuki, E., Akiyama, M., Ono, Y., J. Chem. Soc., Chem. Commun., 136 (1992).

40) Ono, Y., Akiyama, M., Suzuki, E., Chem. Mater, 5, 442 (1993).

41) Suzuki, E., Kusano, S., Hatayama, H., Okamoto, M., Ono, Y., J. Mater. Chem., 7, 2049 (2007).

42) Okamoto, M., You, J., Iwamoto, H., Jpn. Pat. 269788 (2009).

43) Kresge, C. T., Leonowicz, E. M., Roth, W. J., Vartuli, J. C., Beck, J. S., Nature, 359, 710 (1992).

44) Niu, D., Ma, Z., Li, Y., Shi, J., J. Am. Chem. Soc., 132, 15144 (2010).

45) Nakamura, K., Mizutani, M., Nozaki, H., Suzuki, N., Yano, K., J. Phys. Chem. C, 111, 1093 (2007).

46) Suzuki, T. M., Nakamura, T., Sudo, E., Akimoto, Y., Yano, K., J. Catal., 258, 265 (2008).

47) Yano, K., Fukushima, Y., J. Mater. Chem., 13, 2577 (2003).

48) Tan, B., Rankin, S. E., Langmuir, 21, 8180 (2005).

49) Blas, H., Save, M., Pasetto, P., Boissière, C., Sanchez, C., Charleux, B., Langmuir, 24, 13132 (2008).

50) Zhao, W., Lang, M., Li, Y., Li, L., Shi, J., J. Mater. Chem., 19, 2778 (2009).

51) Zhu, Y., Kockrick, E., Ikoma, T., Hanagata, N., Kaskel, S., Chem. Mater., 21, 2547 (2009).
52) Qi, G., Wang, Y., Estevez, L., Switzer, A. K., Duan, X., Yang, X., Giannelis, E. P., Chem. Mater, 22, 2693 (2010).

53) Yamada, Y., Mizutani, M., Nakamura, T., Yano, K., Chem. Mater, 22, 1695 (2010).

54) Kato, N., Ishii, T., Koumoto, S., Langmuir, 26, 14334 (2010).

55) Ogawa, M., Yamamoto, N., Langmuir, 15, 2227 (1999).

56) Fowler, C. E., Khushalani, D., Mann, S., Chem. Commun., 2028 (2001).

57) Rana, R. K., Mastai, Y., Gedanken, A., Adv. Mater, 14, 1414 (2002).

58) Wang, J.-G., Li, F., Zhou, H.-J., Sun, P.-C., Ding, D.-T., Chen, T.-H., Chem. Mater, 21, 612 (2009).

59) Feng, Z., Li, Y., Niu, D., Li, L., Zhao, W., Chen, H., Li, L., Gao, J., Ruan, M., Shi, J., Chem. Commun., 2629 (2008).

60) Li, W. J., Sha, X. X., Dong, W. J., Wang, Z. C., Chem. Commun., 2434 (2002).

61) Li, Y., Shi, J., Hua, Z., Chen, H., Ruan, M., Yan, D., Nano Lett., 3, 609 (2003).

62) Sun, Q., Kooyman, P. J., Grossmann, J. G., Bomans, P. H. H., Frederik, P. M., Magusin, P. C. M. M., Beelen, T. P. M., van Santen, R. A., Sommerdijk, A. J. M., Adv. Mater, 15, 1097 (2003).

63) Zhao, Y., Zhang, J., Li, W., Zhang, C., Han, B., Chem. Commun., 2365 (2009).

64) Yoon, H., Hong, J., Park, C. E., Park, D. W., Shim, S. E., Mater. Lett., 63, 2047 (2009).

65) Teng, Z., Han, Y., Li, J., Yan, F., Yang, W., Micropor. Mesopor. Mater, 127, 67 (2010).

66) Ballem, M. A., Johansson, E. M., Córdoba, J. M., Odén, M., Mater. Lett., 65, 1066 (2011).

67) Okamoto, M., Huang, H., Micropor. Mesopor. Mater., 163, 102 (2012).

要旨

\section{コア-シェル構造の多孔体の合成と触媒および中空材料の前駆体としての利用}

\section{岡本 昌樹}

東京工業大学大学院理工学研究科応用化学専攻, 152-8552 東京都目黒区大岡山2-12-1

ゼオライトや規則性メソ多孔体のような規則性多孔体は, 高 表面積をもち, 大きさが整った細孔径を有する魅力的な材料で ある。これら規則性多孔体の構造や形状を制御することによ り, 新たな機能を付加することができる。本論文では, コアシェル構造に注目し, 久陥の少ないコア-シェル構造を有する ゼオライトの合成法について紹介する。また, 利用例として, コア-シェル構造の MFI およびTON 型ゼオライトを用いた触 媒は, トルエンのメチル化やテトラデカンの骨格異性化におい
て高い形状選択性を示すことについて述べる。さらに，もう一 つの利用例として, コア-シェル構造体を前駆体とした中空多 孔体の合成法についても紹介する。コアにシリカの分解触媒で あるアルカリ金属塩を選択的に担持させ，炭酸ジメチルによる シリカの分解反応を行うことにより, コアのみを取り除くこと ができ, 効率よく中空多孔体を形成することができた。中空多 孔体は, ドラッグデリバリー用の薬物容器や触媒容器, ミクロ 反応容器としての利用が期待できる。 